\title{
ROSA LUXEMBURG: MARXISMO E HISTÓRIA ${ }^{1}$
}

Isabel Maria LOUREIRO²

- RESUMO: Ao interpretar o marxismo como unidade entre teoria e prática, Rosa Luxemburg lança os fundamentos da sua "teoria da ação revolucionária", palavras com que poderíamos sintetizar o seu pensamento político, elaborado numa polêmica ininterrupta com o determinismo economicista da II Internacional.

- UNITERMOS: Marxismo; relação entre teoria e prática; consciência; determinismo; totalidade.

A marcha da história realiza-se certamente de acordo com leis infalíveis. Mas os homens são portadores dessas leis.

Rosa Luxemburg

No começo do século, Mehring publica os escritos do jovem Marx, que Rosa Luxemburg resenha para o Vorwärts ${ }^{3}$. Não podemos dizer que a leitura desses textos tenha modificado substancialmente sua anterior visão do marxismo, tal como aparece em Reforma social ou revolução? ${ }^{4}$, série de artigos polêmicos contra o revisionismo, escritos em 1898-99. Mas com certeza reforçou a tendência "ativista" que nela já existia em germe. Vejamos por quê.

O primeiro período da obra de Marx analisado por Mehring, culminando na publicação dos Anais Franco-Alemães em 1844 e no conhecimento de Engels, mostra-nos, ao mesmo tempo, duas linhas independentes. A primeira manifesta-se na busca da solução do conflito filosófico entre pensar e ser, entre mundo material e processo de pensamento. A outra linha revela-se nos múltiplos contactos com o mundo da prática, isto é, com as questões políticas e econômicas (escritos sobre a censura e a liberdade de imprensa, sobre o roubo de lenha, sobre os vinhateiros do Mosela, sobre a questão judaica).

1. O presente artigo é um capítulo da nossa tese de doutorado Rosa Luxemburg: os dilemas da ação revolucionária, defendida na USP em outubro de 1992.

2. Departamento de Filosofia da Faculdade de Filosofia e Ciências - UNESP - 17525-900 - Marília - SP. 
Na opinião de Mehring, aceita por Rosa, estes últimos trabalhos tiveram para Marx um duplo significado: em primeiro lugar, ao tratar da "miséria alemã prática" (praktische deutsche Misere), ele tomou conhecimento da situação social que acabaria por condenar alguns anos mais tarde. Enquanto seus antigos companheiros da esquerda hegeliana (Bauer, Strauss, Feuerbach) não saíam do terreno das especulações filosóficas abstratas, Marx "formou-se como combatente (Kämpfer) prático." (Luxemburg, 1979, p. 136). Foi essa ligação com a realidade alemã que lhe permitiu, assim que Feuerbach realizou a emancipação do homem da abstração, transformar Rosa cita a Introdução à crítica da filosofia do direito de Hegel - "a crítica do céu (...) na crítica da terra, a crítica da religião na crítica do direito, a crítica da teologia na crítica da política" e formular a pergunta: "Onde se encontra a possibilidade positiva da emancipação alemã?"

Em segundo lugar, o contacto com os problemas práticos mostrou-lhe a insuficiência da sua concepção idealista, levando-o à busca "de um ponto de vista geral, a partir de onde todos os problemas parciais da vida prática e espiritual encontrassem uma elucidação harmônica e uma solução unitária." (Luxemburg, 1979, p. 137).

Esse "ponto de vista geral" a que Marx chegou é central na leitura que Rosa faz do marxismo e já aparecera em Reforma social ou revolução?. Tal como aqui, fundamentada no Capital, também nestas resenhas o recurso ao jovem Marx permite-lhe polemizar com o revisionismo que, ao eliminar a espinha dorsal do materialismo histórico - "a fundamentação histórica na necessidade objetiva, assim como a fundamentação científica na análise econômica" (Luxemburg, 1979, p. 137), - cai num empirismo rasteiro, para o qual a mera observação empírica da exploração capitalista e a consciência da "injustiça" da distribuição da riqueza bastam para legitimar o movimento operário socialista. Rosa frisa que enquanto Marx pensava dessa forma não aderiu ao socialismo.

Na época em que foi redator da Gazeta Renana, desejando submeter o comunismo a uma crítica de fundo, percebeu não bastarem os "fatos empíricos" para criar o "socialismo científico". Faltava-lhe justamente a "concepção monista, unitária do mundo físico e espiritual, do mundo moral e material", isto é, uma concepção cujo fundamento ele encontrou "nas formas sociais da vida" (Luxemburg, 1979, p. 139) e a que chegou pelo caminho da crítica teórica do idealismo hegeliano, não através da observação empírica da miséria.

Em 1898, Rosa já havia censurado o empirismo de Bernstein: este só fora capaz de elaborar uma teoria da adaptação do capitalismo porque, ao examinar certos fenômenos empíricos que iam nessa direção (sistema de crédito, cartéis, fim das crises, permanência das classes médias), perdera de vista a totalidade do desenvolvimento econômico e social: "Nessa teoria, as manifestações todas da vida econômica que acabamos de citar não são estudadas nas suas relações orgânicas com o conjunto do desenvolvimento capitalista e com todo o mecanismo econômico, e sim fora dessas relações, como disjecta membra (partes esparsas) de uma máquina sem vida." (1982, 
p. 405-6; 1970, p. 41). Em outras palavras, a teoria de Bernstein é "mecânica e antidialética" (1982, p. 406; 1970, p. 42)5 , o seu ponto de vista o do capitalista isolado que "considera cada parte orgânica do conjunto econômico como um todo independente." (1982, p. 407; 1970, p. 42)

Em contrapartida, para Luxemburg, Marx pôde decifrar os enigmas da economia capitalista precisamente por tê-la analisado como fenômeno histórico:

O segredo da teoria do valor de Marx, de sua análise do dinheiro, de sua teoria do capital, da taxa de lucro e, por conseguinte, de todo o sistema econômico, está no caráter transitório da economia capitalista, no seu colapso, portanto - este é apenas o outro lado - na finalidade socialista. Justamente e apenas porque Marx considerava em primeiro lugar (von vornherein) como socialista, isto é, de um ponto de vista histórico, a economia capitalista, pôde decifrar-lhe os hieróglifos, e é porque fez do ponto de vista socialista o ponto de partida da análise científica da sociedade burguesa que pôde, por sua vez, dar ao socialismo uma base científica.(1982, p. 416-17; 1970, p. 50) ${ }^{6}$.

Rosa conclui que é a partir do novo ponto de vista totalizante, isto é, revolucionário, que Marx pode desenvolver "um esquema dedutivo da luta de classes e da vitória proletária!" e só então responder à pergunta sobre "a possibilidade positiva da emancipação alemã". (1979, p. 140). Ao mesmo tempo, ao elaborar a noção de proletariado como classe universal, na Introdução à crítica da filosofia do direito de Hegel, ele "criou uma dedução do socialismo, previu a priori a necessidade da vitória e da luta socialistas em vez de agarrar-se ao fato empírico do 'mais produto' e da sua 'injustiça'." (1979, p. 140)7. À luz da dedução é que todos os "fatos empíricos" apareceram para Marx sob um novo enfoque, só quando tinha nas mãos "o fio de Ariadne do materialismo histórico" é que "encontrou, através do labirinto dos fatos quotidianos da sociedade atual, o caminho para as leis científicas do seu desenvolvimento e da sua queda."(1979, p. 141)

Em resumo, o marxismo é, para ela, ao mesmo tempo, uma teoria do desenvolvimento capitalista e uma "filosofia da história " (1979, p. 376), quer dizer, uma teoria na qual o conhecimento das leis que regem o desenvolvimento capitalista indica necessariamente o caminho para a sociedade comunista e que, portanto, nos dá a "garantia da vitória final, da qual haure, não apenas o ímpeto, mas também a paciência, a força para agir e a coragem para perseverar " (1979, p. 372). Ou seja, uma teoria revolucionária da transição do capitalismo ao socialismo. Se, do ponto de vista teórico, não há progresso no marxismo, não é "porque nós, na luta prática, 'superamos' Marx, mas, ao contrário, porque Marx, na sua criação científica, nos superou de antemão como partido de luta prático, não porque Marx não baste mais para as nossas necessidades, mas porque as nossas necessidades ainda não são suficientes para o aproveitamento das idéias marxistas" (1979, p. 368)8.

Nesta perspectiva, o materialismo histórico permite à social-democracia, uma vez conhecida a direção do processo econômico e político na atual sociedade, traçar o seu programa político, não só em grandes linhas, como também nos detalhes. Ou, 
em outras palavras, o marxismo é uma teoria científica que "nos preserva igualmente das surpresas e das ilusões" (Luxemburg, 1979, p. 372) ${ }^{9}$. A política socialista é, nesse sentido, uma política revolucionária que, em oposição à política burguesa, não parte do ponto de vista dos "êxitos quotidianos materiais", mas do ponto de vista da "tendência histórica do desenvolvimento" (Luxemburg, 1979, p. 373), a qual aponta para o colapso do capitalismo. "O objetivo final socialista é o único fator decisivo que distingue o movimento socialdemocrata da democracia burguesa e do radicalismo burguês, o único fator que transforma todo o movimento operário, de um inútil trabalho de remendão para salvar a ordem capitalista numa luta de classes contra essa ordem, pela sua supressão." (Luxemburg, 1982, p. 370; 1970, p. 8). Ou seja, uma vez conhecida a dinâmica histórica consignada na teoria, restaria traduzi-la na ação política ${ }^{10}$, espaço de decisão no tocante a opções táticas ou estratégicas.

Embora Luxemburg, com razão, critique o empirismo de Bernstein, que, abandonando as "armadilhas da dialética", isto é, a categoria da totalidade, considerava fatos empíricos isolados sem conexão entre si, mostrando tão só os mecanismos econômicos de integração do capitalismo no presente, negando-lhe as contradições, e, por conseguinte, a "necessidade econômica imanente" da vitória do socialismo, ao fazê-lo em nome do "objetivo final" socialista como "necessidade histórica" a priori, permite ser censurada por dogmatismo ${ }^{11}$. Ou seja, o materialismo histórico que ela procura opor ao empirismo de Bernstein aparece como uma teoria exterior à luta de classes, contendo uma verdade imune às mudanças históricas. Rosa pôr-se-ia, assim, na posição do teórico que sabe, de antemão, o caminho da história ${ }^{12}$ e, a partir desse ponto de Arquimedes da verdade teórica revolucionária, alheia à prática reformista, atacaria o revisionismo.

Essa crítica tem a sua razão de ser, uma vez que nestes textos o marxismo é caracterizado quase exclusivamente como o "fio de Ariadne", assegurando à socialdemocracia a "vitória final", pois, de posse da teoria, ela é o único partido que "sabe o que faz e por isso faz o que quer."(Luxemburg, 1979, p. 371). Desse ponto de vista, o revisionismo deve ser combatido por desnaturar a teoria, desnaturação que, por sua vez, conduz à prática reformista.

Mas, por outro lado, Rosa percebe que Bernstein é o porta-voz teórico de uma tendência real no movimento operário. Este, no fito de ir além da ordem existente, através de uma luta no interior dessa própria ordem, navega continuamente entre Cila e Caribdes: entre o "abandono do caráter de massa" e o "abandono da finalidade", o "sectarismo" e a "queda no movimento reformista burguês" (1982, p. 443; 1970, p. 77-8). Nessa perspectiva, o revisionismo deixa de ser analisado apenas sob a ótica da "traição" ao "objetivo final", para ser entendido como expressão do "desfalecimento momentâneo da classe operária em ascensão"(1982, p. 445; 1970, p. 79), a qual, de acordo com a crença otimista de Rosa, logo recuperará o élan revolucionário passageiramente perdido.

Esta é, sem a mesma sofisticação teórica, a explicação oferecida por Korsch da teoria de Bernstein, analisada em Marxismo e filosofia como a expressão do "caráter 
real do movimento" (1966, p. 99). Em contrapartida, o marxismo ortodoxo de Kautsky (e, acrescentamos nós, o de Luxemburg, nesse momento) aparece como uma tentativa puramente ideológica de teóricos prisioneiros de uma doutrina já totalmente abstrata naquelas circunstâncias históricas. Aliás, a própria Rosa, que não tinha por objetivo ser guardiã da ortodoxia, acaba dizendo, um pouco mais tarde, que o papel representado pelo marxismo ortodoxo não a atrai nem um pouco, ao perceber sua função meramente ideológica de preservação de princípios teóricos sem qualquer correspondência na prática.

Deve-se, porém, frisar outro aspecto. Rosa encara o desenvolvimento teórico do jovem Marx, ao adotar "o ponto de vista histórico da classe operária" (1979, p. 375) ou, segundo Lukács, o ponto de vista da totalidade (Cf. Lukács, 1975), como uma tentativa bem sucedida de solucionar as antinomias do pensamento burguês. Se a realidade é entendida como totalidade, os problemas econômicos e ideológicos formám uma unidade, uma totalidade concreta de ser e consciência, sujeito e objeto, teoria e prática. Em contrapartida, como bem mostrou o próprio Lukács, o marxismo da IIa Internacional reduziu a teoria a um determinismo que via no fator econômico a causa determinante dos fenômenos sociais. Embora Luxemburg, por um lado, se inscreva nesta vertente, ao mesmo tempo, na medida em que interpreta o marxismo como unidade de teoria e prática - salientando a última - acaba por dar à consciência de classe papel central na sua teoria política, afastando-se, assim, do determinismo economicista em redor.

Alguns autores (Cf. Arato, 1973-74; Basso, 1976; Howard, 1971), na esteira de Lukács, vêem igualmente na categoria da totalidade, "precisamente a essência do marxismo revolucionário" (Basso, 1976, p. 30), a chave para a compreensão do pensamento da nossa autora. Nessa interpretação, o "objetivo final" que ela defende, na polêmica com Bernstein, é compreendido na sua relação com a totalidade do processo histórico, permitindo que cada momento parcial da luta adquira significado revolucionário. "O objetivo final é a totalidade do processo por meio do qual ele é realizado; não é um estado, mas um devir."(Howard, 1971, p. 13). Apenas a necessidade do objetivo final permitiria compreender o presente como um processo em movimento, aberto para o futuro. Caso contrário, a história apareceria como uma série de fatos empíricos descontínuos e fortuitos, sem um sentido imanente. Porém, se a história tem sentido, "nasce uma dialética entre o presente, que ainda não é futuro, e o futuro, para o qual o presente tende. Num presente grávido de futuro, podemos evitar tanto os erros do oportunismo/revisionismo quanto os do utopismo ético" (Howard, 1974, p. 102), quer dizer, do blanquismo.

Vemos, portanto, já nestes primeiros escritos esboçar-se o problema central do pensamento político de Luxemburg: a relação entre a consciência e o processo objetivo da história. Ela retoma, assim, uma questão clássica do marxismo, mas fazendo-o avançar em dois planos: primeiro, inova no que diz respeito à relação recíproca entre espontaneidade e consciência nas ações de massa; segundo, no que 
se refere às relações entre o processo evolutivo da história e a ação revolucionária (Cf. Tych, 1976, p. 135).

A ênfase dada por ela à prática e à consciência decorre precisamente da idéia de criatividade histórica, presente em quase todos os seus escritos - mesmo que os homens não façam a sua história arbitrariamente, são eles que a fazem. Podemos vê-la formulada pela primeira vez em 1902 quando, ao resenhar o livro organizado por Mehring da correspondência de Lassalle com Marx e Engels, considera complementares as suas concepções de história. E mais. Rosa, na esteira de Mehring, acentua o acordo e não a discordância entre Marx e Lassalle, não só do ponto de vista teórico, como prático. Aliás, Lassalle tem forte influência sobre ela, que, nas mais diversas ocasiões, revela viva admiração pelo pensamento e pelo exemplo do revolucionário alemão ${ }^{13}$.

O livro de Mehring, no seu entender, tem o grande mérito de reabilitar Lassalle contra a versão oficial da social-democracia divulgada por Bernstein que, conhecendo as cartas no original e tendo apenas citado algumas passagens no seu prefácio à edição dos escritos de Lassalle, reforçou uma imagem preconcebida a respeito deste, puramente caricatural. Mostra-o - palavras de Bernstein - com "uma autoconfiança sem limites", "vaidade", "impulso a assombrar todo mundo com suas capacidades extraordinárias", falta de "bom gosto e de faculdades morais", "preguiça", "cinismo". Agora, no prefácio de Mehring, ele surge com todas as suas qualidades: vemos o retrato de um "puro caráter antigo: generoso e cristalino na amizade, assim como no ímpeto pelo conhecimento, no desprezo estóico pelas suas próprias dores, assim como no profundo interesse pelo destino alheio."(Luxemburg, 1979, p. 150).

Segundo Luxemburg, desde 1849, quando aparece na cena política, até o início dos anos 60, Lassalle encontra-se em acordo total com Marx nas questões teóricas e práticas fundamentais. A oposição entre eles só começa a aparecer de maneira significativa na polêmica sobre o drama de Lassalle, Franz von Sickingen (cartas de 6 de março e 27 de maio de 1859). A peça dá-lhes a ocasião de debater sobre a "idéia trágica formal" e é aqui que se esboçam as diferenças que mais tarde irão separá-los ${ }^{14}$. No que consistiriam essas diferenças? "Pensamos no espaço deixado à 'decisão individual' que Lassalle defendia, na sua controvérsia com Marx e Engels, contra a 'concepção construtiva da história de Hegel'."(Luxemburg, 1979, p. 154).

Entretanto, segundo Rosa, Lassalle não defende

a 'decisão individual' em oposição à necessidade histórica, mas como expressão, como meio (Medium) dessa necessidade.(...) Em todo caso, é certo que Sickingen precisava fracassar - Marx e Engels tinham absoluta razão - no seu empreendimento. Mas a inutilidade desse empreendimento expressa-se, para Lassalle, em última instância, na contradição interna da ação de Sickingen. Foram as leis históricas que decidiram aqui, mas elas atuaram por meio (durch) da 'decisão individual'. A polêmica entre Marxe Lassalle não consiste, parece-nos, na diferença entre a concepção idealista e a materialista da história, mas muito mais na diferença, no interior desta última, captada por ambos nos seus diferentes momentos. Os homens fazem sua própria história, mas não arbitrariamente, dizem Marx e Engels defendendo a obra da sua vida, a concepção materialista da história de acordo com as leis (gesetzmässige). Os homens não fazem arbitraria- 
mente a história, mas fazem-na eles mesmos - enfatiza Lassalle, defendendo a obra da sua vida, a 'decisão individual', a 'ação audaz' . (...) perante a história, quem acabou tendo razão, Marx ou Lassalle? Ambos. Marx teve razão pois, em condições normais, e para grandes períodos do percurso histórico, apenas a sua teoria representa o norte que pode levar à emancipação da classe operária. Lassalle, porém, acabou tendo razão no seu momento histórico pois, através de um caminho transversal audaz e de um método abreviado, levou a classe operária ao ataque pela mesma larga via histórica em que, desde então, é dirigida pela política de Marx.(Luxemburg, 1979, p. 155-6).

Rosa pergunta-se o que teria sucedido se Sickingen-Lassalle não tivesse cometido erros? Se não tivesse posto como ponto central da sua agitação a ajuda estatal às suas associações de trabalhadores e o sufrágio universal? O resultado histórico teria certamente mudado pouco. A social-democracia na Alemanha, em virtude da "necessidade de bronze da história" teria "passado por cima da eficácia das decisões e atos individuais" e, também, mais cedo ou mais tarde, ter-se-ia tornado poderosa.

Mas Lassalle, ligando sua ação aos fatos concretos, às circunstâncias dadas, sacudiu (rüttelte auf) as massas e chamou a classe operária alemã à vida política, fundando o partido15. "A 'ação audaz' (kühne Tat) acabou tendo razão perante a 'necessidade de bronze da história', que, em curtos períodos de tempo, deixa espaço bastante para desvios de rumo à direita ou à esquerda, para os estéreis erros de Sickingen ou os frutíferos erros de Lassalle ${ }^{16}$. (...) E a 'ação audaz ' só acabou tendo razão perante a 'necessidade de bronze da história' porque era, no sentido históricofilosófico, ação revolucionária."(Luxemburg, 1979, p. 157-8).

Como vemos, a idéia de criatividade histórica aparece neste texto com toda a nitidez. Marx e Engels disseram repetidas vezes que as transformações sociais são produto das leis imanentes do desenvolvimento social e econômico, podendo porém ser aceleradas ou retardadas pela intervenção dos homens. Rosa procura reforçar ainda mais o pólo prático do materialismo histórico, recorrendo a Lassale, símbolo do homem de ação.

Para ela - na esteira do SPD -, havia três pais fundadores da social-democracia alemã: Marx, Engels e Lassalle. Enquanto Marx criara o materialismo histórico - e nisso residia a sua importância - Lassalle fundara o partido, ou seja, pusera em prática o "sọcialismo científico" elaborado por Marx e Engels. Na sua versão, Lassalle é o revolucionário audaz, entusiasmado, que, apesar dos equívocos (estatismo, colaboração com Bismarck), Rosa elege como fonte de inspiração revolucionária para a social-democracia alemã (Cf. 1984, p. 183, 208). Aliás, na sua leitura, o que unia Marx e Lassalle era a "fé na revolução" (Glaube an die Revolution) (1979, p. 419). Com isso, Rosa atacava a desvinculação operada pelo SPD entre teoria e prática.

A unidade entre esses dois pólos é, portanto, segundo a nossa autora, constituinte do materialismo histórico. Independentemente da conjuntura e dos alvos polêmicos, reafirma sempre que o marxismo é composto de dois elementos essenciais: de um lado, a análise, a crítica, o método histórico de pesquisa e, de outro, “a vontade ativa da classe operária, que constitui o elemento revolucionário. Quem não puser em 
prática senão a análise, a crítica, não representa o marxismo, mas uma triste paródia dessa doutrina." (Luxemburg, 1981, p. 224). O que faltou à social-democracia foi justamente "a vontade ativa (tatkräftige) de fazer a história " (Luxemburg, 1987, p. 31), isto é, faltou-lhe a política revolucionária. Para contrapor-se ao doutrinarismo de um Kautsky, afirma freqüentemente que em Marx estavam indissoluvelmente ligados o homem de ação e o teórico, o historiador e o revolucionário.

Mesmo no Capital ela busca o aspecto prático, revolucionário. Aliás, Rosa considera que, no primeiro volume do Capital, Marx lançou as bases do socialismo, motivo pelo qual o movimento socialista só levou em conta essa parte da obra. Do ponto de vista da luta de classes, o problema teórico mais importante é o da origem da mais-valia, "isto é, a explicação científica da exploração, aliada à elucidação da tendência para a socialização do processo de produção, quer dizer, a explicação científica do fundamento objetivo da revolução (Umwälzung) socialista" (1979, p. 336), problemas resolvidos no primeiro volume. Também na Introdução à economia política, diz, no mesmo sentido, que com Marx a economia política acabou do ponto de vista teórico. A continuação só pode ocorrer no plano da prática, da ação, isto é, na luta pelo socialismo. "O último capítulo da doutrina da economia política é a revolução social do proletariado" (1985, p. 592).

Em resumo, a análise do desenvolvimento capitalista mostra que tanto o colapso quanto a revolução são "inevitáveis", porém a ação do proletariado é necessária para desentranhar o núcleo de racionalidade contido na história. Caso contrário, esta não passará de uma possibilidade teórica. Ou seja, sem a atividade consciente da classe operária não há socialismo possível. Até no momento mais pessimista da sua carreira política - 1914-1916 -, quando as esperanças revolucionárias haviam desaparecido do horizonte próximo, Rosa Luxemburg (e o grupo Spartakus) continua a ver na futura ação revolucionária das massas o eixo da política socialista, e na presente agitação do partido (o grupo de oposição) uma forma de despertá-las.

Isto posto, o que chama a atenção e a distingue de um Kautsky, mesmo na época em que ambos estavam juntos contra o revisionismo, é o peso atribuído à consciên$\mathrm{Cia}^{17}$, elemento desprezado pelo marxismo da II Internacional. Kautsky - o teórico mais representativo dessa corrente - , como sabemos, interpreta o marxismo enquanto teoria da evolução social, que mostra os fenômenos sociais regidos por leis semelhantes às da natureza:

"A evolução social foi integrada (...) (por Marx) nos quadros da evolução natural; o espírito humano, até nos seus fenômenos mais complicados e mais elevados, foi representado como parte da natureza; foi demonstrado que, em todos os terrenos, a sua atividade obedece a leis naturais, e que o idealismo filosófico e o dualismo não têm a menor base sólida."(Kautsky, 1933, p. 20).

No âmbito da evolução natural, entendida nos moldes darwinistas de luta pela vida, a luta de classes é apenas um capítulo, uma parte dessa história natural que se move por oposições. Conseqüentemente, a revolução proletária não passa também de um momento particular da lei geral da evolução natural. É portanto inevitável, 
necessária. Como está na ordem das coisas, não cabe aos homens impedi-la nem apressá-la ${ }^{18}$. No materialismo histórico, entendido enquanto "ciência proletária" (Kautsky, 1933, p. 22), base da "marcha triunfal"(Kautsky, 1933, p. 62) da social democracia em todo mundo, segundo Kautsky, a consciência de classe tem papel secundário.

Para marcar as diferenças entre Kautsky e Luxemburg, nunca será demais enfatizar, contra as interpretações da nossa autora como determinista e mesmo fatalista, que a "garantia da vitória final" não tem para ela o estatuto de uma lei da natureza, na medida em que o socialismo apenas será possível se as massas se apoderarem da teoria marxista, se houver a união entre o conhecimento e a classe operária ${ }^{19}$ : "A transformação histórica formulada na teoria marxista tem como pressuposto que essa teoria se torne a forma de consciência da classe operária e, como tal, um elemento da história."(Luxemburg, 1979, p. 373). A teoria de Marx é "uma parte do processo histórico, logo também ela própria um processo e a revolução social será o capítulo final do Manifesto Comunista." (Luxemburg, 1979, p. 373) Por conseguinte, essa teoria só será superada "junto com a atual ordem social." (Luxemburg, 1979, p. 377).

Mesmo em obras de forte caráter economicista como Reforma social ou revolução?, A acumulação do capital e a Anticnítica, onde insiste na teoria do colapso, Luxemburg repete que o socialismo não resulta automaticamente das contradições objetivas do capitalismo, que é necessário o "conhecimento subjetivo, por parte da classe operária, da inelutabilidade da supressão da economia capitalista por meio de uma revolução (Umwälzung) social" (1982, p. 403). Ou seja, ela compreendeu, desde o início da sua carreira política, que a economia por si só não levará ao socialismo ${ }^{20}$.

Justamente por conceber a história como um processo em que as leis do desenvolvimento histónico, isto é, a "tendência histórica do desenvolvimento", a "tendência para a socialização do processo de produção" não se separam da "ação audaz" - "não basta que o pensamento tenda para a realização, a realidade deve tender para o pensamento" - , ou, em outras palavras, que em toda formação social e econômica há unidade entre fator material e fator espiritual, concepção posteriormente enriquecida em Greve de massas, partido e sindicatos por uma análise da relação entre a espontaneidade das massas e a ação consciente, é que a sua propostapolítica se afasta tanto do reformismo quanto do blanquismo ${ }^{21}$. Rosa salienta constantemente que o socialismo precisa ao mesmo tempo de um solo objetivo - as contradições do capitalismo - e da tomada de consciência da classe operária quanto à necessidade da revolução. Em torno deste eixo organiza-se o seu pensamento político.

Contudo, malgrado a ação revolucionária (e, por conseguinte, a consciência) estar sempre presente nos seus textos, no início é antes uma idéia vaga, uma orientação do pensamento sem conteúdo muito determinado, uma coadjuvante promissora, mas por enquanto apenas coadjuvante. É na análise da relação partido/classe, ação consciente/ação espontânea que esse conceito vai adquirindo espessura, mais precisamente, a partir de 1904, quando aparece ligado à noção de massa, 
tornando-se doravante o protagonista principal. Entretanto, já um texto de outubro de 1903, "Geknickte Hoffnungen" (Neue Zeit), citando uma passagem da Sagrada Família, apontava nesse sentido:

Porém - já escrevia Marx em 1845 -, 'com a profundidade da ação histórica, aumentará também o volume da massa engajada nessa ação'. A luta de classe proletária é a mais 'profunda' de todas as ações históricas até hoje, ela abrange a totalidade das camadas inferiores do povo e, desde que existe a sociedade de classes, é a primeira ação que corresponde ao interesse próprio da massa. Por isso, o conhecimento próprio da massa quanto às suas tarefas e caminhos é condição histórica indispensável para a ação social-democrata, assim como o desconhecimento da massa foi outrora a condição das ações das classes dominantes. Assim a oposição entre os 'chefes' e a maioria que 'vai atrás' é abolida, a relação entre massas e chefes é posta de ponta-cabeça. O único papel dos pretensos 'chefes' na social-democracia consiste em esclarecer a massa sobre as suas tarefas históricas. (Luxemburg, 1979, p. 396).

Rosa volta continuamente ao tema da diferença entre o movimento socialista, que abrange a totalidade dos de baixo exigindo-lhes consciência, e os grupos de conspiradores blanquistas, cuja tática consistia no terrorismo e no golpe de Estado, e onde a massa ignorante vivia dominada pelos líderes. Ela percebia claramente que o blanquismo era apenas a contrapartida organizatória de um movimento de massas fraco, em que um punhado de conspiradores "fazia" a revolução, "ignorando todas as condições histórico-sociais concretas" (1981, p. 329). Em suma, o blanquismo era voluntarista, crendo poder modelar o mundo à força, de acordo com seus ideais, sem levar em conta o processo objetivo da história.

Ao contrário, no movimento socialista, as massas alcançavam, no trabalho político e sindical, consciência dos fins e dos meios para atingi-los, o que levaria precisamente a uma mudança na relação entre dirigentes e dirigidos. O papel dos dirigentes consistiria então em esclarecer a massa sobre os seus interesses históricos, muitas vezes obscurecidos pela ideologia dominante, e não em comandá-la, com base num saber elaborado fora da classe que, eternamente presa às reivindicações imediatas, nunca conseguiria universalizar os seus interesses. Isso seria apanágio da vanguarda. Contrariamente a essa concepção autoritária da política, própria do blanquismo, Rosa defende "a organização e a ação autônoma e direta da massa." (1991, p. 42).

Mas é no famoso artigo polêmico contra Lenin, Questões de organização da social-democracia russa, que a noção de massa, ligada à de autonomia, começa a ter papel central no seu pensamento político. Opondo-se à idéia leninista de um partido vanguarda fortemente centralizado e disciplinado, introduzindo de fora a consciência nas massas passivas, obedientes e desorganizadas, ela mostra como a experiência histórica revela precisamente o inverso, a ação espontânea da classe operária russa, desde o final do século XIX, impondo mudanças táticas ao partido: "Em suas grandes linhas, a tática de luta da social-democracia não é de modo algum 'inventada', mas é o resultado de uma série ininterrupta de grandes atos criadores da luta de classes experimental, freqüentemente elementar. Também aqui o inconsciente precede 0 
consciente, a lógica do processo histórico objetivo precede a lógica subjetiva dos seus portadores." (Luxemburg, 1991, p. 47).

A massa tem caráter dinâmico, não é apenas objeto da ação do movimento operário organizado, mas sobretudo sujeito desse movimento. Na fórmula lapidar: "(...) o único sujeito a que agora cabe o papel de dirigente é o eu-massa (das Massen-Ich) da classe operária, que em todo lugar insiste em poder fazer os seus próprios erros e aprender por si mesmo a dialética histórica."(Luxemburg, 1991, p. 59).

Entretanto, só em Greve de massas, partido e sindicatos todas estas idéias são minimamente sistematizadas. Como sempre ocorre na sua obra, a teoria é formulada a partir da análise concreta de uma situação concreta. No presente caso, os acontecimentos de 1905-1906 na Rússia oferecem a contribuição fundamental para a sua teoria da ação revolucionária ${ }^{22}$.

\section{Notas}

3. O livro de Mehring intitula-se Aus dem literanischen Nachlass von Karl Marx, Friedrich Engels und Ferdinand Lassalle. Bd. I: Gesammelte Schriften von Karl Marx und Friedrich Engels. Von März 1841 bis März 1844; Bd. II: Von Juli 1844 bis November 1847; Bd.III: Von Mai 1848 bis Oktober 1850; Bd. IV: Briefe von Ferdinand Lassalle an Karl Marx und Friedrich Engels, Stuttgart, 1902. As resenhas têm por título "Aus dem Nachlass unserer Meister", e foram publicadas entre setembro de 1901 e novembro de 1902 (Cf. Luxemburg, 1979).

4. Procuramos fugir, neste trabalho, na medida do possível, ao esquema corriqueiro de apresentação da obra da autora que começa sempre analisando Reforma social ou revolução?, deixando na sombra os textos aqui tratados. Como justamente a polêmica com Bernstein é bem conhecida, limitamo-nos a mencioná-la en passant, dando por pressuposto o conhecimento do leitor.

5. O que para Bernstein é uma virtude e não um defeito. A seus olhos, a dialética é a "armadilha hegeliana" que impede Marx e Engels de terem uma concepção realista do desenvolvimento capitalista (Cf. Bernstein, 1982, p. 127-32).

6. Michel Löwy considera decisiva esta interpretação do marxismo na elaboração de uma teoria da práxis revolucionária (Cf. 1975, p. 98-9). A idéia da unidade entre teoria e prática repete-se na resenha sobre as Teorias da mais-valia, de Marx (Cf. Luxemburg, 1979, p. 462) e, mais tarde, na Introdução à economia política (Cf. Luxemburg, 1985, p. 587).

7. Os grifos são de Rosa Luxemburg.

8. Korsch, com toda razão, critica a exterioridade entre teoria e prática que aparece nesta passagem (Cf. 1966, p. 28).

9. É esse aspecto determinista em Luxemburg que permitiu à vulgata marxista-leninista na ex-RDA interpretar a sua teoria como uma "Weltanschauung científica": "Como Weltanschauung do proletariado, o marxismo era para Rosa Luxemburg uma ideologia militante que decifrou para o proletariado as leis do desenvolvimento social em geral e as leis do 
movimento da formação social capitalista em particular, que revelou ao proletariado a sua missão histórica; uma Weltanschauung que, estreitamente ligada à organização proletária, transformaria radicalmente o mundo no sentido do progresso da humanidade." (Radczum, 1969, p. 52).

10. Em Reforma social ou revolução?, esta idéia de uma teoria pronta, apontando o caminho à classe operária, é assim formulada: "Se nosso programa contém a formulação do desenvolvimento histórico da sociedade do capitalismo ao socialismo, então evidentemente deve formular também, em todos os traços fundamentais, todas as fases transitórias desse desenvolvimento e, por conseguinte, deve poder indicar ao proletariado, a cada momento, que comportamento lhes deve corresponder, no sentido do encaminhamento para o socialismo." (Luxemburg, 1982, p. 433-4; 1970, p. 68).

11. "O leitor é forçado a perguntar no que consiste o princípio regulador a priori de toda teoria e prática socialistas: na historicidade do colapso necessário do capitalismo, na tomada do poder pelo proletariado ou no futuro socialista? Lidamos com uma teoria completamente determinista ou completamente voluntarista?" (Arato, 1973-74, p. 15).

12. Como bem observou Howard: se o que distingue o socialismo da democracia burguesa e do radicalismo burguês é apenas "esta crença apriorística no 'objetivo final', não se pode esclarecer a pesquisa paciente e detalhada de Marx na elaboração do Capital: o Capital torna-se uma construção. Se o marxismo começa supondo a necessidade da revolução, é então uma teoria circular, muito parecida à doutrina cristã do 'pecado original' " (1974, p. 101-2).

13. Rosa segue Mehring na sua interpretação de Lassalle. Para Mehring, o idealismo era ao mesmo tempo o ponto fraco e o ponto forte de Lassalle: dava-lhe a fé inabalável no poder da idéia, que lhe permitiu fazer coisas poderosas. "E se, como economista era inferior a Marx, como revolucionário nada tinha a invejar-lhe, a menos que se lhe queira censurar o fato de que o arrebatamento infatigável de suas energias revolucionárias desbordasse a infatigável paciência do investigador científico. Todas as suas obras - com a única exceção do Heráclito - perseguiam uma eficácia prática imediata." (1957, p. 331) O que tanto Rosa Luxemburg quanto Mehring valorizam em Lassalle é o seu instinto revolucionário e, sobretudo, sua sede de verdade (Cf. Mehring, 1960, p. 573-619).

14. Fritz J. Raddatz, na sua introdução à Werkauswahl de Franz Mehring, escreve a respeito do Sickingen: "A tragédia do indivíduo histórico de Lassalle não só faz declaradamente parte da sucessão de Schiller como também, no seu esboço intelectual, não pode ser entendida sem Schiller. É o prolongamento do idealismo num progressivo utopismo." (1974, p. 47) Há todo um debate em torno do Sickingen em que é impossivel entrar (Cf. Lukács, 1965; s.d.). Também Mehring estuda o Sickingen na sua História da social-democracia alemã, não se detendo no aspecto estético da obra, que considera fraco: "poesia abstrata e erudita". O que lhe interessa nesse drama, em que catástrofes históricas são abstratamente concebidas como conflitos de idéias, é precisamente o problema da relação entre meios e fins, posto na ação revolucionária. "Por isso, Lassalle perguntava-se: por que e em que Sickingen fracassou? Como transformar pensamento revolucionário em ações revolucionárias? Como resolver a contradição, que salta aos olhos, ao primeiro passo prático do revolucionário, entre a força do entusiasmo, a coerência radical dos princípios, por um lado, e, por outro, o intelecto calculador, a necessária unilateralidade de toda política? À profunda contradição dialética inserida na natureza de toda ação e tanto mais 
da ação revolucionária, chama Lassalle a idéia trágica formal da sua tragédia histórica."(Mehring, 1960, p. 598-9).

15. A mesma idéia aparece mais tarde, em 1913, num artigo intitulado "Lassalles Erbschaft": "Com ou sem Lassalle a social-democracia alemã teria nascido, assim como com ou sem Marx e Engels a luta de classes do proletariado internacional ter-se-ia tornado o fator dominante da história moderna. Entretanto, que o partido da classe proletária na Alemanha tenha surgido, com tal esplendor e nobreza, já há cinquenta anos, duas décadas mais cedo que em todos os outros países e como modelo para todos os outros, devêmo-lo à obra de Lassalle e ao seu 'Eu ousei!' ."(Luxemburg, 1984, p. 220). Embora compreensível, não deixa de ser curioso que, ao comemorar os 50 anos de existência da social-democracia alemã, Rosa Luxemburg faça remontar as origens do SPD não a Bebel e Liebknecht, que, em 1869, em Eisenach, criaram o Sozialdemokratische Arbeiterpartei Deutschlands, aliado de Marx, mas a Lassalle e à sua Allgemeiner Deutscher Arbeiterverein, fundada em 1863, a cujo rígido centralismo Rosa não faz referência, neste momento. Mas em 1904, polemizando com Lenin, opusera o "centralismo extremado" do partido de Lassalle ao "autonomismo" dos eisenachianos (Luxemburg, 1991, p. 54).

16. Rosa, aliás, refere-se muito rapidamente aos erros de Lassalle (o estatismo que se transforma em apoio ao Estado prussiano) e menciona longamente seus acertos: nunca hesitou, pela "ação audaz", em denunciar o liberalismo burguês alemão e em mostrar ao proletariado alemão o caminho para uma política de classe independente. Se Lassalle reduziu a sua luta a algumas palavras de ordem - crédito estatal, sufrágio universal, associações produtivas - não foi por acreditar que o socialismo poderia ser lentamente introduzido por reformas, mas por impaciência, por querer encurtar o longo processo histórico e concentrar o ataque em poucos pontos. "Assim, mesmo os erros de tática de Lassalle foram os do revolucionário impetuoso (Stürmer) e não os do indeciso, do revolucionário destemido, e não os do diplomata pusilânime." (Luxemburg, 1979, p. 419). Ele, assim como Marx e Engels, viveu na crença profunda da legitimidade e inevitabilidade da revolução proletária e, além disso, compreendeu que a revolução é obra das massas e não do parlamento (Cf. Luxemburg, 1979, p. 420). Mehring (e podemos acrescentar também RL), como observa Ragionieri, é condescendente com a tática de Lassalle: acordo com os Junker e o Estado prussiano para impor as reivindicações operárias à burguesia alemã. Em contrapartida, Marx e Engels encaravam a possibilidade de uma revolução democrática na Alemanha em que a classe operária fizesse avançar a burguesia alemã, eliminando assim os restos feudais e alcançando a unidade nacional a partir de baixo e não por cima (Cf. Ragioniere, p. XLI).

17. "Rosa Luxemburg foi a primeira teórica da social-democracia a considerar sistematicamente a importância do fator subjetivo." (Arato, p. 24). Mencione-se, a título de curiosidade, que em carta a Leo Jogiches, de 28.3.1899, Rosa pede-lhe que escreva sobre o papel da consciência, para inserir nos artigos contra Bernstein. Porém, não foi possivel, por falta de tempo. Outras cartas de 8 e 12.5.1899 a Jogiches fazem referência a um artigo difícil que está escrevendo sobre a consciência (Cf. Luxemburg, 1982-84).

18. Diz Kautsky: "Tudo que existe tem, por força, de sucumbir, hoje ou amanhã, vítima de um desequilíbrio entre dois princípios contrários. E isto não é aplicável somente às plantas e aos animais, mas às sociedades, aos impérios, aos corpos celestes. Por toda parte, o progresso do processo geral da evolução prepara, pelo crescimento insensível das resis- 
tências, catástrofes momentâneas. (...) Estas constituem uma fase necessária da evolução: não há evolução sem que haja, de tempos a tempos, uma revolução." (1933, p. 26-27).

19. No prefácio de 1899, Reforma social ou revolução?, escreve: "Não se poderia insultar mais grosseiramente, desprezar mais fortemente o operariado (Arbeiterschaft) que pretender que discussões teóricas são unicamente coisa de 'intelectuais'. Lassalle já disse outrora: Unicamente quando a ciência e o operário, esses dois pólos opostos da sociedade, se unirem, é que afastarão, com mão de ferro, todos os obstáculos no caminho da civilização. Todo o poder do movimento operário moderno repousa sobre o conhecimento teórico." (1982, p. 371.) A mesma idéia retorna na Introdução à economia política (Cf.1985, p. 593).

20. Por isso não é possível concordar totalmente com a interpretação de Marco Aurélio Garcia segundo a qual Rosa, no debate com Bernstein, é tributária da tese catastrofista - a idéia de que o capitalismo será abatido por suas próprias contradições (Cf. Garcia, 1991). A nosso ver, já nesse momento, ela percebe a importância da consciência de classe na revolução. O que decorre da sua interpretação do marxismo como unidade entre teoria e prática. Não podemos esquecer que Rosa polemiza com Bernstein, donde a ênfase no fator objetivo, totalmente desprezado por ele. Mais tarde, em 1907, no Congresso de Stuttgart, diz: "Para nós, a dialética histórica não é válida no sentido de que assistimos a ela, de braços cruzados, até que nos traga frutos maduros. Sou uma partidária convicta do marxismo e considero justamente como um grande perigo dar ao marxismo aquela forma rígida, fatalista (...)" (1981, p. 237). Rosa, aliás, já na época do Bernstein Debatte, refutava a interpretação economicista do materialismo histórico: "se está fora de dúvida que os fatores econômico e político exercem constantemente uma influência alternativa sobre o devir social, é o fator econômico que, em última instância, permanece característico e determinante e por isso designei-o como o 'motor' da vida social. Mas no que concerne à 'falsa interpretação do materialismo', segundo a qual os fatores econômicos teriam sido os únicos fundamentos do desenvolvimento, estou persuadida de que ela tem apenas uma existência mítica na sua imaginação. Os materialistas que pretendem que 0 desenvolvimento econômico corre alegremente sobre a via histórica, como uma locomotiva autônoma, e que a política, a ideologia, etc. contentam-se em trotar atrás dela como vagões de mercadorias desamparados e passivos, você não encontrará traço de uma concepção dessas, mesmo na mais longínqua província russa (...); e se alguma vez você encontrar um tal prodígio, faça-o expor no gabinete das figuras de cera." (carta a Robert Seidel, 15.8.1898, Gesammelt Briefe).

21. Contra o reformismo, ver Reforma social ou revolução?; contra o blanquismo, ver $\grave{A}$ memória do Proletariat, uma análise do partido polonês Proletariat em que mostra suas origens simultaneamente social-democratas e blanquistas. Ver também Questões de organização da social-democracia russa, contra a concepção leninista do partido vanguarda centralizado. Em 1907, diz Rosa: "Certamente o verdadeiro marxismo está tão longe da superestimação unilateral do parlamento quanto da concepção mecânica da revolução e da superestimação da assim chamada insurreição armada. Nisto, meus camaradas poloneses e eu temos opinião diferente da dos camaradas bolcheviques." (1981, p. 222).

22. Nettl considera que em Greve de massas, partido e sindicatos, texto analisado em outro capítulo de nossa tese, "todos os elementos importantes da doutrina já estavam presentes (...), houve poucas mudanças, ainda menos elementos novos nos escritos posteriores." (1972, p. 487). 
LOUREIRO, I. M. Rosa Luxemburg: Marxism and History, Trans/Form/Ação, São Paulo, v. 16, p. 83-98, 1993.

- ABSTRACT: Rosa Luxemburg's interpretation of Marxism as the unity between theory and practice sets the basis of her "theory of revolutionary action". That expression can be said to encapsulate her political thought, which was developed in an uninterrupted polemic with the economicist determinism of the Second International.

- KEYWORDS: Marxism; relationship between theory and practice; consciousness; determinism; totality.

\section{Referências bibliográficas}

ARATO, A. The Second International: a reexamination. Telos. Washington, n. 18, winter, 1973-74.

BASSO, L. El pensamiento politico de Rosa Luxemburg. Barcelona: Peninsula, 1976.

BERNSTEIN, E. Las premisas del socialismo y las tareas dela socialdemocracia. México: Siglo Veintiuno, 1982.

GARCIA, M. A. A questão da revolução e Rosa Luxemburg. In: LOUREIRO, I. M., VIGEVANI, T. (Org.), Rosa Luxemburg, a recusa da alienação. São Paulo: Unesp, 1991.

HOWARD, D. Introdução a Rosa Luxemburg. Selected Political Writings. Nova York/ Londres: Monthly Review Press, 1971.

Theorie, Theoretiker und revolutionäre Praxis. In: POZZOLI, C. (Org.). Rosa

Luxemburg oder die Bestimmung des Sozialismus. Frankfurt: Suhrkamp, 1974.

KAUTSKY, K. A realização histórica de Karl Marx. In: LUXEMBURG, LENIN. O marxismo. São Paulo: Unitas, 1933.

KORSCH, K. Marxismo e Filosofia. Porto: Afrontamento, 1966.

LÖWY, M. Rosa Luxemburgo. In: Método dialético e teoria política. Rio de Janeiro:

Paz e Terra, 1975.

LUKÁCS, G. Franz Mehring. In: Aportaciones a la historia de la estetica. Mexico: Grijalbo, 1965. . Rosa Luxemburg como marxista. In: Historia y consciencia de classe.

Barcelona: Grijalbo, 1975. O debate sobre o'Sickingen' de Lassalle. In: Marx e Engels como historia-

dores da literatura. Porto: Nova Crítica, s.d.

LUXEMBURG, R. Reforma, Revisionismo e Oportunismo. Rio de Janeiro: Laemmert, 1970. . Gesammelte Briefe. Berlim: Dietz, 1982-84. v.1. Gesammelte Werke, Berlim: Dietz, 1982. v. 1/1. Gesammelte Werke, Berlim: Dietz, 1979. v. 1/2. Gesammelte Werke, Berlim: Dietz, 1981. v. 3. . Gesammelte Werke, Berlim: Dietz, 1984. v. 3. Gesammelte Werke, Berlim: Dietz, 1987. v. 4. . Gesammelte Werke, Berlim: Dietz, 1985. v. 5. 
LUXEMBURG, R. Questões de organização da social-democracia russa. In: A Revolução Russa. Petrópolis: Vozes, 1991.

MEHRING, F. Carlos Marx, historia de su vida. Mexico: Grijalbo, 1957. Geschichte der deutschen Sozialdemokratie. In: Gesammelte Schriften I. Berlim: Dietz, 1960.

NETTL, J. P. La vie et l'oeuvre de Rosa Luxemburg. Paris: Maspero, 1972.

RADCZUN, G. Einige Bemerkungen zu dem Rosa-Luxemburg-Bild von John Peter Nettl. Beiträge zur Geschichte der deutschen Arbeiterbewegung. Berlim, v. 1, 1969.

RADDATZ, F. J. Die Mehring-Legende. Introdução a Franz Mehring. Werkauswahl. Darmstadt/Neuwied: Luchterland, 1974. v. 1.

RAGIONIERI, E. Prefácio à Storia della socialdemocracia tedesca. Roma: Riuniti, 1974.

TYCH, F. Masses, classes et parti chez Rosa Luxemburg. In: GRISONI. D. (Org.). Histoire du marxisme contemporain. Paris: Union Générale d'Editions, 1976. v. 2. 